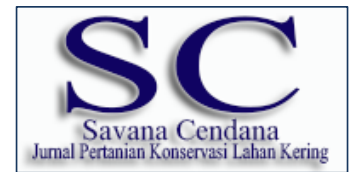

\title{
Pengaruh Komposisi Media Tanam dan Ukuran Polybag Terhadap Pertumbuhan dan Hasil Tomat (Licopercicum escelentum, Mill)
}

\section{Florentina Buia ${ }^{\mathrm{a}}$, Maria Afnita Lelang ${ }^{\mathrm{b}}$, Roberto I. C. O. Taolin ${ }^{\mathrm{c}}$}

${ }^{a}$ Fakultas Pertanian, Universitas Timor, Kefamenanu, TTU - NTT, 85613, Indonesia, email: florentinabui@ gmail.com

b Fakultas Pertanian, Universitas Timor, Kefamenanu, TTU - NTT, 85613, Indonesia, email: afnitalelang@ymail.com

c Fakultas Pertanian, Universitas Timor, Kefamenanu, TTU - NTT, 85613, Indonesia, email: ricotaolin@gmail.com

\section{Article Info}

\section{Article history:}

Received 14 September 2015

Received in revised form 12 Oktober 2015

Accepted 15 Oktober 2015

Keywords:

Media Tanam

Tomat

Polybag

\begin{abstract}
Abstrak
Penelitian ini bertujuan untuk mengetahui pengaruh dan membuktikan komposisi media tanam dan ukuran polybag yang dapa memberikan pertumbuhan dan hasil tanaman tomat terbaik. Rancangan yang digunakan adalah rancangan acak kelompok (RAK) faktorial dengan tiga kali ulangan. Faktor pertama adalah komposisi media tanam yang merupakan campuran tanah, arang sekam dan pupuk kandang yang terdiri dari tiga aras yakni 1:2:3, 2:1:3 dan 3:2:1. Faktor yang kedua adalah ukuran polybag yang terdiri dari tiga aras yakni $15 \times 20 \mathrm{~cm}, 20 \times 20 \mathrm{~cm}$ dan $20 \times 25 \mathrm{~cm}$. Hasil penelitian menunjukkan interaksi antara komposisi media tanam dan ukuran polybag hanya terjadi pada tinggi tanaman 14 HST dan berat buah per tanaman panen III. Komposisi media tanam berpengaruh nyata terhadap diameter batang 28 HST dan 42 HST, berat buah per tanaman panen I, panen II dan panen III, berat segar maupun kering berangkasan. Sedangkan ukuran polybag berpengaruh nyata terhadap suhu tanah setiap waktu pengamatan, tinggi tanaman 14 HST dan 28 HST, diameter batang 28 HST, luas daun, berat per buah, jumlah buah per tanaman, berat buah per tanaman panen I, panen II, panen III dan total panen, berat segar maupun kering berangkasan dan berat kering akar. Media tanam dengan komposisi 1:2:3 memberikan hasil total panen per tanaman tertinggi yakni $964,5 \mathrm{~g}$ dibandingkan komposisi media tanam $2: 1: 3$ dan $3: 2: 1$. Penggunaan polybag dengan ukuran 20 × 25 memberikan hasil total panen per tanaman tertinggi yaitu 1.022,7 g dibandingkan ukuran polybag $15 \times 20$ dan $20 \times 20$ (c)2016 dipubikasikan oleh Savana Cendana.
\end{abstract}

\section{Pendahuluan}

Tomat merupakan tanaman sayuran yang penting karena buah tomat mengandung vitamin $\mathrm{C}$ dan vitamin A yang memiliki banyak manfaat untuk kesehatan. Zat asam askorbat dan karoten, yang terkandung dalam tomat, merupakan sumber zat yang sangat penting dan dapat meningkatkan aktifitas tubuh. Kandungan vitaminnya dapat mencengah berbagai penyakit atau berfungsi sebagai obat sariawan, gusi dan rabun ayam, sehingga toma tergolong sayuran yang memiliki nilai ekonomis tinggi (Susanto dan Saneto, 1994).

Dalam budidaya tanaman termasuk tomat, faktor lingkungan memegang peranan penting untuk mencapai pertumbuhan dan hasil yang maksimal. Hayati et al. (2012) menyatakan bahwa faktor lingkungan sangat berperan dalam proses pertumbuhan tanaman, media tumbuh adalah salah satu faktor lingkungan yang perlu dipertimbangkan. Selanjutnya juga dinyatakan bahwa media tanam yang baik biasanya digunakan campuran pasir, tanah, pupuk kandang. Penggunaan pasir sangat baik untuk perbaikan sifat fisik tanah terutama tanah liat.

Menurut Wuryaningsih (2008) media tanam adalah media yang digunakan untuk menumbuhkan tanaman, tempat akar atau bakal akar akan tumbuh dan berkembang, media tanam juga digunakan tanaman sebagai tempa berpegangnya akar, agar tajuk tanaman dapat tegak kokoh berdiri di atas media tersebut dan sebagai sarana untuk menghidupi tanaman.

Media tanam yang baik harus memenuhi persyaratan tertentu seperti tidak mengandung bibit hama dan penyakit, bebas gulma, mampu menampung air, tetapi juga mampu membuang atau mengalirkan kelebihan air, remah dan porous sehingga akar bisa tumbuh dan berkembang menembus media tanam dengan mudah dan derajat keasaman $(\mathrm{pH})$ antara 6-6,5 (Anonim, 2007) Sedangkan menurut Wira (2000) bahan-bahan untuk media tanam dapat dibua dari bahan tunggal ataupun kombinasi dari beberapa bahan, asalkan tetap berfungsi sebagai media tumbuh yang baik. Menurut Prastowo dan Roshetko (2006) syarat media pembibitan yang baik adalah ringan, murah, mudah didapat, porus (gembur) dan subur (kaya unsur hara).

Osman (1996) menyatakan bahwa tanah dengan keadaan tekstur dan struktur yang baik sangat menunjang keberhasilan usaha pertanian, struktur tanah yang dikehendaki tanaman adalah struktur tanah yang gembur mempunyai ruang pori yang berisi air dan udara sehingga penyerapan unsur hara dapat berjalan optimal. Menurut Nyakpa dan Hasinah (1985) pupuk kandang dapat menambah unsur hara dalam tanah sebagai penyediaan humus yang dapat memperbaiki struktur tanah dan mendorong kehidupan jasad renik tanah

Arang sekam padi juga dapat digunakan sebagai bahan media tanam, menurut Rifai dan Subroto (1982) sekam padi merupakan hasil sampingan dari sisa-sisa pembakaran. Unsur hara yang terkandung dalan sekan padi relatif cepat tersedia bagi tanaman dan dapat meningkatkan $\mathrm{pH}$ tanah. Selanjutnya menurut Prihmantoro dan Indriani (2003) arang sekam mempunyai sifat yang mudah mengikat air, tidak mudah menggumpal, harganya relatif murah, bahannya mudah didapat, ringan, steril dan mempunyai porositas yang baik.

Selain komposisi media tanam, volume media juga merupakan fakto penentu keberhasilan usaha pertanian. Menurut Muliawati (2001), penggunaan tanah lebih efisien dapat dilakukan dengan mengurangi volume media yang diisikan ke dalam polybag. Volume media yang baik untuk budidaya tanaman adalah volume media yang mampu menunjang pertumbuhan dan perkembangan akar serta mencukupi kebutuhan tanaman akan air dan unsur hara. Manipulas volume media yang tepat adalah dengan membuat komposisi media yang dapat mempertahankan kelembaban tanah dalam waktu relatif lebih lama dan mampu menyediakan unsur hara bagi tanaman.

Volume media tanam berhubungan langsung dengan ukuran polybag yang digunakan dalam budidaya tanaman. Permasalahannya adalah belum diketahu komposisi media tanam dan ukuran polybag yang dapat menunjang pertumbuhan agar tomat dapat berproduksi secara maksimal, oleh karena itu perlu dilakukan penelitian tentang pengaruh komposisi media tanam dan ukuran polybag terhadap pertumbuhan dan hasil tanaman tomat. Penelitian ini bertujuan untuk mengetahui pengaruh dan membuktikan komposisi media tanam dan ukuran polybag yang dapat memberikan pertumbuhan dan hasi tanaman tomat terbaik

\section{Metode}

2.1 Waktu dan Tempat

Penelitian ini dilaksanakan pada bulan Juni - September 2015 di kebun penelitian Fakultas Pertanian Universitas Timor, Kelurahan Sasi Kecamatan Kota Kefamenanu, Kabupaten Timor Tengah Utara, Propinsi Nusa Tenggara Timur, Topografi dengan Ketinggian $300-400 \mathrm{~m}$ dpl curah hujan $900-1500$ mm per tahun, suhu udara berkisar antar $22-35^{\circ} \mathrm{C}$ dan $\mathrm{pH} 6,5$ (BPS, 2007).

2.2 Rancangan Percobaan

Rancangan yang digunakan dalam penelitian ini adalah rancangan acak kelompok (RAK) faktorial dengan tiga kali ulangan. Faktor pertama adalah komposisi media tanam yang merupakan campuran tanah, arang sekam dan pupuk kandang $(\mathrm{K})$ yang terdiri dari tiga aras yakni $1: 2: 3\left(\mathrm{k}_{1}\right), 2: 1: 3\left(\mathrm{k}_{2}\right)$ dan 3:2:1 $\left(\mathrm{k}_{3}\right)$. Faktor yang kedua adalah ukuran polybag $(\mathrm{V})$ yang terdiri dari tiga aras yakni $15 \times 20 \mathrm{~cm}\left(\mathrm{v}_{1}\right), 20 \times 20 \mathrm{~cm}\left(\mathrm{v}_{2}\right)$, dan $20 \times 25 \mathrm{~cm}\left(\mathrm{v}_{3}\right)$. Kombinasi perlakuannya adalah $\mathrm{k}_{1} \mathrm{v}_{1}, \mathrm{k}_{1} \mathrm{v}_{2}, \mathrm{k}_{1} \mathrm{v}_{3}, \mathrm{k}_{2} \mathrm{v}_{1}, \mathrm{k}_{2} \mathrm{v}_{2}, \mathrm{k}_{2} \mathrm{v}_{3}, \mathrm{k}_{3} \mathrm{~s}_{1}, \mathrm{k}_{3} \mathrm{v}_{2}$ dan $\mathrm{k}_{3} \mathrm{v}_{3}$ sehingga terdapat 27 satuan percobaan.

2.3 Pelaksanaan Penelitian

a. Persiapan Benih

Benih yang digunakan dalam penelitian ini adalah benih tomat varietas Lentana F1 dengan kemurnian benih $99 \%$ dan daya tumbuh $95 \%$. Benih dibeli dari toko sarana produksi pertanian sebanyak satu bungkus dengan isi bersih 1.750 butir.

b. Persemaian

Persemaian berupa bale-bale dengan ukurannya tinggi $100 \mathrm{~cm}$, lebar 100 $\mathrm{cm}$, panjang $150 \mathrm{~cm}$. Media semai berupa campuran tanah ayakan $\pm 15 \mathrm{~kg}$ dengan pupuk kandang $\pm 2 \mathrm{~kg}$ dan pasir secukupnya. Benih ditaburkan secara merata kemudian ditutup dengan tanah yang tipis dan disiram air dengan hatihati. Pada umur 23 hari, benih dipindahkan langsung ke polybag yang sudah disiapkan

c. Persiapan Lahan

Lahan tempat penelitian dibersihkan dari gulma atau tanaman lain. Selanjutnya dilakukan pembentukan lahan percobaan berukuran panjang 210 $\mathrm{cm}$ dan lebar $70 \mathrm{~cm}$ yang dibatasi dengan tali raffia. Petak yang dibentuk berjumlah 27 petak yang dibagi dalam tiga blok. Jarak antar petak adalah $50 \mathrm{~cm}$ dan jarak antar blok $100 \mathrm{~cm}$. Luas lahan secara keseluruhan adalah $89,6 \mathrm{~m}^{2}$ dengan panjang $10,8 \mathrm{~m}$ dan lebar $8,3 \mathrm{~m}$. Lahan percobaan kemudian diberi naungan setinggi $2 \mathrm{~m}$ menggunakan daun kelapa dan atap dibuka secara bertahap selama proses pertumbuhan sampai terbuka secara menyeluruh.

d. Persiapan Media Tanam

Media tanam yang digunakan berupa tanah, arang sekam dan pupuk kandang sapi. Tanah yang digunakan adalah top soil yang telah dibersihkan dari bahan-bahan kotoran kemudian diayak. Arang sekam diperoleh dengan cara membakar sekam padi hingga menjadi arang, sedangkan pupuk kandang yang digunakan adalah pupuk kandang sapi yang telah matang. Ketiga media 
tersebut kemudian dicampur menggunakan ember dengan perbandingan sesuai perlakuan selanjutnya media dimasukan dalam 378 polybag. 126 polybag (42 polybag ukuran $15 \times 20,42$ polybag ukuran 20 × 20 dan 42 polybag ukuran 20 $x$ 25) diisi media dengan komposisi 1:2:3, 126 polybag (42 polybag ukuran 15 x 20,42 polybag ukuran 20 x 20 dan 42 polybag ukuran $20 \times 25$ ) diisi media dengan komposisi 2:1:3 dan 126 polybag (42 polybag ukuran 15 x 20, 42 polybag ukuran $20 \times 20$ dan 42 polybag ukuran $20 \times 25$ ) diisi media dengan komposisi 3:2:1. Polybag kemudian disusun dalam petak-petak percobaan dan diinkubasi selama dua minggu. Pada setiap blok, petak, tanaman sampel dan tanaman korban diberikan label menggunakan tiang bambu dan seng.

e. Penanaman

Penanaman dilakukan menggunakan bibit tanaman telah memiliki 4 - 5 helai daun. Sebelum polybag disiram terlebih dahulu kemudian tiap polybag ditanami satu bibit tanaman. Penanaman dilakukan sore hari. Bibit ditanam dengan cara membenamkannya bersama media ke dalam lubang tanam sebatas leher akar. Setelah melakukan penanaman, bibit disiram dengan air secukupnya. f. Pemeliharaan

Penyiraman tomat dilakukan menggunakan selang irigasi yang dilakukan dua kali sehari, yaitu pagi dan sore. Penyiangan dilakukan untuk mengurangi atau membersikan rumput-rumput dan sejenis tumbuhan lain yang merupakan pengganggu tanaman. Kegiatan penyiangan yang dilakukan apabila menemukan adanya gulma menggunakan tajak. Penyulaman dilakukan dengan cara mengganti tanaman yang mati, rusak atau pertumbuhan tidak normal dengan tanaman yang telah disiapkan. Pada umur 21 HST tanaman mengalami klorosis daun mengguning mulai dipucuk daun muda sampe ketulang daun tetapi daun tetap segar yaitu pada blok I pada komposisi media tanam 2:1:3 ukuran polybag 20 × 20 dan ukuran polybag $15 \times 20$ sedangkan pada blok II dikomposisi media tanam 3:2:1 ukuran polybag 15 x 20 dan komposisi 1:2:3 ukuran polybag $20 \times 20$ kemudian disemprot dengan pupuk daun (Mitra Flora). Pengendalian hama dilakukan dengan memetik dan membuang buah tomat yang terserang hama ulat Heliotis armigera yang awal mula mengebor buah sambil memakannya sehingga terjadi kerusakan buah, buah yang rusak berjumlah 105 buah.

g. Panen

Buah tomat dipanen pada saat masak fisiologis yang ditandai dengan warna tomat kemerah-merahan dengan cara dipetik. Pemanenan dilakukan 3 kali yaitu pada saat tomat berumur 78 HST, 93 HST, 99 HST dan 105 HST. Panen yang keempat dilakukan secara rampasan atau panen semua buah.

2.4 Parameter Pengamatan

a. Suhu Tanah $\left({ }^{\circ} \mathrm{C}\right)$

Pengukuran suhu tanah dilakukan tiga kali selama penelitian yakni -1 HST, 30 HST dan 60 HST, menggunakan thermometer suhu tanah, dengan cara ditancapkan pada kedalaman tanah $5 \mathrm{~cm}$ selama 3 menit pada tiga titik untuk setiap petak. Pengukuran dilakukan pada siang hari pukul 12.00-14.00 WITA

b. Tinggi Tanaman $(\mathrm{cm})$

Tinggi tanaman diukur dari pangkal batang sampai ujung daun paling tinggi, pengukuran menggunakan pengaris centimeter. Pengukuran dilakukan pada lima tanaman sampel saat berumur 14 HST, 28 HST dan 42 HST.

c. Diameter Batang (mm)

Pengukuran diameter batang dilakukan dengan menggunakan jangka sorong dengan cara menjepit pada bagian batang $(1 \mathrm{~cm}$ di atas pangkal batang) dari lima tanaman sampel pada setiap petak. Pengukuran dilakukan pada saat tanaman berumur 14 HST, 28 HST dan 42 HST.

d. Luas Daun $\left(\mathrm{cm}^{3}\right)$

Pengukuran luas daun dilakukan pada saat pertumbuhan vegetatif maksimum (42 HST). Pengukuran luas daun dilakukan menggunakan metode fotografi dengan cara mengambil semua daun pada tiga tanaman korban pada tiap petak, kemudian daun dipotret menggunakan kamera digital. Luas area daun kemudian dihitung menggunakan program ImageJ versi 1.41 o.

e. Diameter Buah (mm)

Pengukuran diameter buah dilakukan dengan menggunakan jangka sorong dengan cara menjepit pada bagian buah yang terbesar. Buah yang diukur adalah semua buah yang dipanen dari lima tanaman sampel pada setiap petak kemudian dirata-ratakan. Pengukuran dilakukan setiap kali panen kemudian dirata-ratakan untuk memperoleh ukuran diameter buah.

f. Berat Per Buah $(\mathrm{g})$

Berat per buah diukur dengan cara menimbang buah tomat menggunakan timbangan analitik. Buah yang ditimbang adalah semua buah yang dipanen dari setiap tanaman sampel pada semua petak kemudian dirata-ratakan dengan cara berat total dibagi dengan jumlah buah. Pengukuran dilakukan setiap kali panen. g. Jumlah Buah Per Tanaman

Buah yang dipanen dari lima tanaman sampel dihitung kemudian dirataratakan. Perhitungan dilakukan setiap kali panen kemudian dijumlahkan untuk mendapatkan jumlah buah tomat per tanaman.

h. Berat Buah Per Tanaman (g)

Berat buah per tanaman diukur dengan cara menimbang buah tomat menggunakan timbangan analitik. Buah yang ditimbang adalah semua buah yang dipanen dari lima tanaman sampel pada setiap petak kemudian dirataratakan dengan cara berat total dibagi dengan jumlah tanaman sampel. Pengukuran dilakukan setiap kali panen kemudian dijumlahkan untuk memperoleh ukuran berat buah per tanaman total panen.

i. Panjang Akar $(\mathrm{cm})$

Panjang akar diukur dengan menggunakan penggaris pada akar lima tanaman sampel. Akar diukur mulai dari leher akar yaitu batas antara batang dengan akar hingga ujung akar. Pengukurannya dilakukan setelah panen.

j. Berat Segar Berangkasan $(\mathrm{g})$

Berat segar berangkasan diukur dengan cara menimbang berangkasan lima tanaman sampel dalam setiap petak yang telah dipanen. Pengukuran menggunakan timbangan duduk.

k. Berat Kering Akar (g)

Berat kering akar diukur dengan cara menimbang akar lima tanaman sampel yang telah dipanen dan dijemur selama satu minggu. Pengukuran menggunakan timbangan duduk.

1. Berat Kering Berangkasan $(\mathrm{g})$

Berat kering berangkasan diukur dengan cara menimbang berangkasan lima tanaman sampel (tanpa akar) yang telah dipanen dan dijemur selama satu minggu. Pengukuran menggunakan timbangan duduk.

m. Rasio Akar Tajuk

Rasio akar tajuk dihitung dengan cara membandingkan berat kering akar dengan berat kering berangkasan tanpa akar.

n. Indeks Panen (\%)

Indeks panen dihitung dengan cara membandingkan berat bagian tanaman yang bernilai ekonomis dengan berat bagian seluruh tanaman kemudian dikonversikan ke satuan \%. Indeks panen dihitung dengan rumus.

$$
\begin{array}{cl} 
& \mathrm{IP}=\frac{\mathrm{A}}{\mathrm{A}+\mathrm{B}} \text { X } 100 \% \\
\text { Keterangan } & : \\
\text { IP } & \text { : Indeks Panen }(\%) \\
\text { A } & \text { : Berat Buah Per Tanaman }(\mathrm{g}) \\
\text { B } & \text { : Berat Segar Brangkasan }(\mathrm{g})
\end{array}
$$

2.5 Analisis Data

Semua data yang diperoleh ditabulasikan kemudian dianalisa dengan menggunakan sidik ragam (Anova) Rancangan Acak Kelompok (RAK), selanjutnya untuk mengetahui pengaruh perlakuan yang diberikan, rata-rata perlakuan diuji lanjut menggunakan Duncan Multiple Range Test (DMRT) pada jenjang $5 \%$ sesuai petunjuk Gomez dan Gomez (1995). Analisis data menggunakan program SAS 9.1 .

\section{Hasil dan Pembahasan}

a. Suhu Tanah

Suhu tanah selama penelitian berfluktuasi dari pengamatan awal hingga pengamatan terakhir dengan kisaran suhu antara $23,9-31,1{ }^{\circ} \mathrm{C}$. Hasil sidik ragam (Anova) menunjukkan tidak terjadi pengaruh interaksi antara komposisi media tanam dan ukuran polybag terhadap suhu tanah setiap waktu pengamatan.

\begin{tabular}{|c|c|c|c|c|c|}
\hline \multirow{2}{*}{$\begin{array}{c}\text { Waktu } \\
\text { Pengamatan }\end{array}$} & \multirow{2}{*}{$\begin{array}{l}\text { Komposisi } \\
\text { Media }\end{array}$} & \multicolumn{3}{|c|}{ Ukuran Polybag } & \multirow{2}{*}{ Rerata } \\
\hline & & $15 \times 20$ & $20 \times 20$ & $20 \times 25$ & \\
\hline \multirow{4}{*}{$-1 \mathrm{HST}$} & $1: 2: 3$ & $25,2 \mathrm{ab}$ & $25,0 \mathrm{ab}$ & $23,9 \mathrm{~b}$ & $24,7 \mathrm{a}$ \\
\hline & $2: 1: 3$ & $25,8 \mathrm{a}$ & $25,4 \mathrm{ab}$ & $24,5 \mathrm{ab}$ & $25,3 \mathrm{a}$ \\
\hline & $3: 2: 1$ & $25,3 \mathrm{ab}$ & $25,2 \mathrm{ab}$ & $24,6 \mathrm{ab}$ & $25,0 \mathrm{a}$ \\
\hline & Rerata & $25,4 \mathrm{a}$ & $25,2 \mathrm{a}$ & $24,3 \mathrm{~b}$ & $(-)$ \\
\hline \multirow{4}{*}{$30 \mathrm{HST}$} & $1: 2: 3$ & $31,1 \mathrm{a}$ & 29,2 bcd & $28,1 \mathrm{~d}$ & $29,5 \mathrm{a}$ \\
\hline & $2: 1: 3$ & $30,2 \mathrm{abc}$ & 29,7 abcd & $28,4 \mathrm{~d}$ & 29,4 a \\
\hline & $3: 2: 1$ & $30,9 \mathrm{ab}$ & $28,8 \mathrm{~cd}$ & $28,0 \mathrm{~d}$ & $29,2 \mathrm{a}$ \\
\hline & Rerata & $30,7 \mathrm{a}$ & $29,2 \mathrm{~b}$ & $28,2 \mathrm{c}$ & $(-)$ \\
\hline \multirow{4}{*}{$60 \mathrm{HST}$} & $1: 2: 3$ & $27,8 \mathrm{ab}$ & $27,4 \mathrm{ab}$ & $26,1 \mathrm{~b}$ & $27,1 \mathrm{a}$ \\
\hline & $2: 1: 3$ & $28,9 \mathrm{a}$ & $25,8 \mathrm{~b}$ & $26,4 \mathrm{~b}$ & $27,0 \mathrm{a}$ \\
\hline & $3: 2: 1$ & $28,7 \mathrm{~b}$ & $26,9 \mathrm{ab}$ & $26,6 \mathrm{~b}$ & $27,4 \mathrm{a}$ \\
\hline & Rerata & $28,5 \mathrm{a}$ & $26,7 \mathrm{~b}$ & $26,3 \mathrm{~b}$ & $(-)$ \\
\hline
\end{tabular}


Komposisi media tanam tidak berpengaruh nyata pada suhu tanah setiap waktu pengamatan tetapi data pada Tabel 1. menunjukkan bahwa pada waktu pengamatan -1 HST suhu tanah pada media tanam dengan komposisi 2:1:3 cenderung lebih tinggi sedangkan suhu tanah pada media tanam dengan komposisi 1:2:3 paling rendah, selanjutnya pada pengamatan 30 HST suhu tanah pada media tanam dengan komposisi 1:2:3 cenderung lebih tinggi sedangkan suhu tanah pada media tanam dengan komposisi $3: 2: 1$ paling rendah dan saat pengamatan 60 HST suhu tanah pada media tanam dengan komposisi 3:2:1 cenderung lebih tinggi sedangkan suhu tanah pada media tanam dengan komposisi 2:1:3 paling rendah.

Ukuran polybag berpengaruh nyata pada suhu tanah setiap waktu pengamatan dimana saat pengamatan -1 HST suhu tanah dalam polybag berukuran $15 \times 20$ paling tinggi dan berbeda nyata dengan suhu tanah pada polybag yang berukuran $20 \times 25$ tetapi tidak berbeda nyata dengan suhu tanah dalam polybag berukuran $20 \times 20$, sedangkan pada pengamatan selanjutnya suhu tanah dalam polybag berukuran $15 \times 20$ masih tetap paling tinggi dan berbeda nyata dengan suhu tanah pada polybag yang berukuran 20 x 20 maupun suhu tanah pada polybag yang berukuran $20 \times 25$.

b. Tinggi Tanaman

Tanaman terus bertambah tinggi selama penelitian. Hasil sidik ragam (Anova) menunjukkan terjadi pengaruh interaksi antara komposisi media tanam dan ukuran polybag terhadap tinggi tanaman saat pengamatan 14 HST dimana tanaman yang ditanam pada media tanam dengan komposisi 1:2:3 dengan menggunakan polybag ukuran $15 \times 20$ paling tinggi dan berbeda nyata dengan tinggi tanaman yang ditanam pada media tanam dengan komposisi 1:2:3 dengan menggunakan polybag ukuran $20 \times 25$ tetapi tidak berbeda nyata dengan tinggi tanaman yang diberikan kombinasi perlakuan yang lainnya. Pada waktu pengamatan selanjutnya tidak terjadi pengaruh interaksi antara komposisi media tanam dan ukuran polybag terhadap tinggi tanaman.

Komposisi media tanam tidak berpengaruh nyata pada tinggi tanaman setiap waktu pengamatan tetapi data pada Tabel 2. menunjukkan bahwa tanaman yang ditanam pada media tanam dengan komposisi 2:1:3 selalu cenderung lebih tinggi setiap kali pengamatan sedangkan tanaman yang ditanam pada media tanam dengan komposisi 1:2:3 paling pendek saat 14 HST dan 42 HST, tanaman yang ditanam pada media tanam dengan komposisi 3:2:1 paling pendek saat 28 HST.

Ukuran polybag berpengaruh nyata terhadap tinggi tanaman waktu pengamatan 14 HST dan 28 HST dimana saat 14 HST tanaman yang ditanam dalam polybag dengan ukuran 15 × 20 paling tinggi dan berbeda nyata dengan tinggi tanaman yang ditanam dalam polybag dengan ukuran 20 x 25 tetapi tidak berbeda nyata dengan tinggi tanaman yang ditanam dalam polybag dengan ukuran 20 x 20, sebaliknya saat pengamatan 28 HST tanaman yang ditanam dalam polybag dengan ukuran $20 \times 25$ paling tinggi dan berbeda nyata dengan tinggi tanaman yang ditanam dalam polybag dengan ukuran $15 \times 20$ tetapi tidak berbeda nyata dengan tinggi tanaman yang ditanam dalam polybag dengan ukuran 20 x 20. Pada pengamatan 42 HST ukuran polybag tidak lagi berpengaruh secara nyata tetapi tanaman yang ditanam dalam polybag dengan ukuran 20 × 20 cenderung lebih tinggi sedangkan tanaman yang ditanam dalam polybag dengan ukuran $20 \times 25$ berukuran paling pendek.

\begin{tabular}{|c|c|c|c|c|c|}
\hline \multirow{2}{*}{$\begin{array}{c}\text { Waktu } \\
\text { Pengamatan }\end{array}$} & \multirow{2}{*}{$\begin{array}{c}\text { Komposisi } \\
\text { Media }\end{array}$} & \multicolumn{3}{|c|}{ Ukuran Polybag } & \multirow{2}{*}{ Rerata } \\
\hline & & $15 \times 20$ & $20 \times 20$ & $20 \times 25$ & \\
\hline \multirow{4}{*}{$-1 \mathrm{HST}$} & $1: 2: 3$ & $18,2 \mathrm{a}$ & $15,2 \mathrm{~b}$ & $12,5 \mathrm{c}$ & $15,3 \mathrm{a}$ \\
\hline & $2: 1: 3$ & $16,2 \mathrm{ab}$ & $15,6 b$ & $15,4 \mathrm{~b}$ & $15,7 \mathrm{a}$ \\
\hline & $3: 2: 1$ & $14,6 \mathrm{bc}$ & $16,5 \mathrm{ab}$ & $15,6 \mathrm{~b}$ & $15,6 \mathrm{a}$ \\
\hline & Rerata & $16,3 \mathrm{a}$ & $15,8 \mathrm{ab}$ & $14,5 \mathrm{~b}$ & $(+)$ \\
\hline \multirow{4}{*}{$30 \mathrm{HST}$} & $1: 2: 3$ & $50,9 \mathrm{ab}$ & $49,3 \mathrm{bc}$ & $49,8 \mathrm{c}$ & $50,0 \mathrm{a}$ \\
\hline & $2: 1: 3$ & $48,5 \mathrm{~b}$ & $50,8 \mathrm{ab}$ & $57,8 \mathrm{ab}$ & $52,4 \mathrm{a}$ \\
\hline & $3: 2: 1$ & $41,6 \mathrm{ab}$ & $50,4 \mathrm{ab}$ & $52,0 \mathrm{ab}$ & $48,0 \mathrm{a}$ \\
\hline & Rerata & $47,0 \mathrm{~b}$ & $50,2 \mathrm{ab}$ & $53,2 \mathrm{a}$ & $(-)$ \\
\hline \multirow{4}{*}{$60 \mathrm{HST}$} & $1: 2: 3$ & $77,7 \mathrm{a}$ & $81,2 \mathrm{a}$ & $58,3 \mathrm{a}$ & $72,4 \mathrm{a}$ \\
\hline & $2: 1: 3$ & $75,0 \mathrm{a}$ & $82,7 \mathrm{a}$ & $78,6 \mathrm{a}$ & $78,8 \mathrm{a}$ \\
\hline & $3: 2: 1$ & $67,7 \mathrm{a}$ & $78,8 \mathrm{a}$ & $80,3 \mathrm{a}$ & $75,6 \mathrm{a}$ \\
\hline & Rerata & $73,5 \mathrm{a}$ & $80,9 \mathrm{a}$ & $72,4 \mathrm{a}$ & $(-)$ \\
\hline
\end{tabular}

\section{c. Diameter Batang}

Batang tanaman terus bertambah besar selama penelitian. Hasil sidik ragam (Anova) menunjukkan tidak terjadi pengaruh interaksi antara komposisi media tanam dan ukuran polybag terhadap diameter batang setiap waktu pengamatan.

Komposisi media tanam tidak berpengaruh nyata pada diameter batang tanaman saat 14 HST tetapi data pada Tabel 3. menunjukkan bahwa batang tanaman yang ditanam pada media tanam dengan komposisi 2:1:3 sama besar dengan batang tanaman yang ditanam pada media tanam dengan komposisi
1:2:3 dan cenderung lebih tinggi dibandingkan dengan batang tanaman yang ditanam pada media tanam dengan komposisi 3:2:1. Pada pengamatan selanjutnya komposisi media tanam berpengaruh nyata pada diameter batang dimana saat 28 HST batang tanaman yang ditanam pada media tanam dengan komposisi 2:1:3 paling besar dan berbeda nyata dengan diameter batang tanaman yang ditanam pada media tanam dengan komposisi 3:2:1 tetapi tidak berbeda nyata dengan diameter batang tanaman yang ditanam pada media tanam dengan komposisi 1:2:3.

Tabel 3. Diameter Batang (mm)

\begin{tabular}{|c|c|c|c|c|c|}
\hline \multirow{2}{*}{$\begin{array}{c}\text { Waktu } \\
\text { Pengamatan }\end{array}$} & \multirow{2}{*}{$\begin{array}{l}\text { Komposisi } \\
\text { Media }\end{array}$} & \multicolumn{3}{|c|}{ Ukuran Polybag } & \multirow{2}{*}{ Rerata } \\
\hline & & $15 \times 20$ & $20 \times 20$ & $20 \times 25$ & \\
\hline \multirow{4}{*}{14 HST } & $1: 2: 3$ & $3,3 \mathrm{a}$ & $3,1 \mathrm{a}$ & $2,8 \mathrm{a}$ & $3,1 \mathrm{a}$ \\
\hline & $2: 1: 3$ & $3,1 \mathrm{a}$ & $3,2 \mathrm{a}$ & $3,1 \mathrm{a}$ & $3,1 \mathrm{a}$ \\
\hline & $3: 2: 1$ & $2,9 \mathrm{a}$ & $3,1 \mathrm{a}$ & $3,1 \mathrm{a}$ & $3,0 \mathrm{a}$ \\
\hline & Rerata & $3,1 \mathrm{a}$ & $3,2 \mathrm{a}$ & $3,0 \mathrm{a}$ & $(-)$ \\
\hline \multirow{4}{*}{$28 \mathrm{HST}$} & $1: 2: 3$ & $6,6 \mathrm{c}$ & $7,3 \mathrm{~b}$ & $7,7 \mathrm{c}$ & $7,2 \mathrm{ab}$ \\
\hline & $2: 1: 3$ & $7,0 \mathrm{ab}$ & $7,1 \mathrm{ab}$ & $7,9 \mathrm{a}$ & $7,3 \mathrm{a}$ \\
\hline & $3: 2: 1$ & $6,4 \mathrm{ab}$ & $6,8 \mathrm{a}$ & $7,4 \mathrm{ab}$ & $6,8 \mathrm{~b}$ \\
\hline & Rerata & $6,7 \mathrm{~b}$ & $7,1 \mathrm{~b}$ & $7,6 \mathrm{a}$ & $(-)$ \\
\hline \multirow{4}{*}{$42 \mathrm{HST}$} & $1: 2: 3$ & 8,6 a & $6,0 \mathrm{a}$ & $8,0 \mathrm{ab}$ & $7,5 \mathrm{a}$ \\
\hline & $2: 1: 3$ & $7,9 \mathrm{a}$ & $4,9 \mathrm{a}$ & $6,2 \mathrm{~b}$ & $6,3 \mathrm{a}$ \\
\hline & $3: 2: 1$ & $3,5 \mathrm{a}$ & $1,6 \mathrm{a}$ & $3,7 \mathrm{ab}$ & $2,9 \mathrm{~b}$ \\
\hline & Rerata & $6,7 \mathrm{a}$ & $4,2 \mathrm{a}$ & $6,0 \mathrm{a}$ & $(-)$ \\
\hline
\end{tabular}

Saat 14 HST, ukuran polybag tidak berpengaruh nyata terhadap diameter batang tetapi batang tanaman yang ditanam dalam polybag dengan ukuran $20 \mathrm{x}$ 20 cenderung lebih besar sedangkan batang tanaman yang ditanam dalam polybag dengan ukuran $20 \times 25$ paling kecil. Saat 28 HST ukuran polybag berpengaruh nyata terhadap diameter batang dimana batang tanaman yang ditanam dalam polybag dengan ukuran 20 x 25 paling besar dan berbeda nyata dengan batang tanaman yang ditanam dalam polybag dengan ukuran 15 x 20 maupun 20 × 20 . Pada pengamatan 42 HST ukuran polybag tidak lagi berpengaruh secara nyata tetapi batang tanaman yang ditanam dalam polybag dengan ukuran 15 x 20 cenderung lebih besar sedangkan batang tanaman yang ditanam dalam polybag dengan ukuran 20 × 20 berukuran paling kecil.

d. Luas Daun

Hasil sidik ragam (Anova) menunjukkan tidak terjadi pengaruh interaksi antara komposisi media tanam dan ukuran polybag terhadap luas daun. 
Tabel 4. Luas Daun $\left(\mathrm{cm}^{2}\right)$

\begin{tabular}{ccccc}
\hline Komposisi & \multicolumn{3}{c}{ Ukuran Polybag } & \multirow{2}{*}{ Rerata } \\
\cline { 2 - 4 } Media & $15 \times 20$ & $20 \times 20$ & $20 \times 25$ & \\
\hline $1: 2: 3$ & $1612 \mathrm{~d}$ & $2302 \mathrm{bcd}$ & $2810 \mathrm{ab}$ & $2241 \mathrm{a}$ \\
$2: 1: 3$ & $1618 \mathrm{~d}$ & $2454 \mathrm{abc}$ & $3186 \mathrm{a}$ & $2419 \mathrm{a}$ \\
$3: 2: 1$ & $1801 \mathrm{~cd}$ & $2003 \mathrm{~cd}$ & $2286 \mathrm{bcd}$ & $2030 \mathrm{a}$ \\
\hline Rerata & $1677 \mathrm{c}$ & $2253 \mathrm{~b}$ & $2761 \mathrm{a}$ & $(-)$ \\
\hline Keterangan : & $\begin{array}{l}\text { Angka pada baris dan kolom yang diikuti dengan huruf yang sama tidak berbeda nyata } \\
\end{array}$ & menurut uji DMRT a5\%.( - $)$ : Tidak terjadi interaksi antar faktor &
\end{tabular}

Komposisi media tanam tidak berpengaruh nyata terhadap luas daun tetapi data pada Tabel 4. menunjukkan bahwa permukaan daun tanaman yang ditanam pada media tanam dengan komposisi 2:1:3 cenderung lebih luas sedangkan permukaan daun tanaman yang ditanam pada media tanam dengan komposisi $1: 2: 3$ paling sempit.

Ukuran polybag berpengaruh nyata terhadap luas daun dimana permukaan daun tanaman yang ditanam dalam polybag dengan ukuran 20 x 25 paling luas dan berbeda nyata dengan luas daun tanaman yang ditanam dalam polybag dengan ukuran $15 \times 20$ maupun $20 \times 20$.

\section{e. Diameter Buah}

Hasil sidik ragam (Anova) menunjukkan tidak terjadi pengaruh interaksi antara komposisi media tanam dan ukuran polybag terhadap diameter buah.

Komposisi media tanam tidak berpengaruh nyata terhadap diameter buah tetapi data pada Tabel 5. menunjukkan bahwa buah dari tanaman yang ditanam pada media tanam dengan komposisi 1:2:3 cenderung lebih besar sedangkan buah dari tanaman yang ditanam pada media tanam dengan komposisi 3:2:1 paling kecil. Ukuran polybag juga tidak berpengaruh nyata terhadap diameter buah tetapi buah dari tanaman yang ditanam dalam polybag dengan ukuran $20 \mathrm{x}$ 20 cenderung lebih besar sedangkan diameter buah dari tanaman yang ditanam dalam polybag dengan ukuran 20 x 25 paling kecil.

Tabel 5. Diameter Buah (mm)

\begin{tabular}{ccccc}
\hline Komposisi & \multicolumn{3}{c}{ Ukuran Polybag } & \multirow{2}{*}{ Rerata } \\
\cline { 2 - 4 } Media & $15 \times 20$ & $20 \times 20$ & $20 \times 25$ & \\
\hline $1: 2: 3$ & $3,83 \mathrm{a}$ & $4,07 \mathrm{a}$ & $4,21 \mathrm{a}$ & $4,04 \mathrm{a}$ \\
$2: 1: 3$ & $3,88 \mathrm{a}$ & $3,98 \mathrm{a}$ & $4,17 \mathrm{a}$ & $4,01 \mathrm{a}$ \\
$3: 2: 1$ & $3,96 \mathrm{a}$ & $3,98 \mathrm{a}$ & $2,71 \mathrm{a}$ & $3,55 \mathrm{a}$ \\
\hline Rerata & $3,89 \mathrm{a}$ & $4,01 \mathrm{a}$ & $3,70 \mathrm{a}$ & $(-)$ \\
\hline Keterangan $:$ & Angka pada baris dan kolom yang diikuti dengan huruf yang sama tidak berbeda nyata \\
& menurut uji DMRT a5\%. (-) : Tidak terjadi interaksi antar faktor &
\end{tabular}

f. Berat Per Buah

Hasil sidik ragam (Anova) menunjukkan tidak terjadi pengaruh interaksi antara komposisi media tanam dan ukuran polybag terhadap berat per buah. Komposisi media tanam tidak berpengaruh nyata terhadap berat per buah tetapi data pada Tabel 6. menunjukkan bahwa setiap buah dari tanaman yang ditanam pada media tanam dengan komposisi 1:2:3 cenderung lebih berat sedangkan setiap buah dari tanaman yang ditanam pada media tanam dengan komposisi $2: 1: 3$ paling ringan.

Ukuran polybag berpengaruh nyata terhadap berat per buah dimana buah dari tanaman yang ditanam dalam polybag dengan ukuran $20 \times 25$ paling berat dan berbeda nyata dengan berat per buah dari tanaman yang ditanam dalam polybag dengan ukuran $15 \times 20$ maupun $20 \times 20$.

Tabel 6. Berat Per Buah (g)

\begin{tabular}{ccccc}
\hline Komposisi & \multicolumn{3}{c}{ Ukuran Polybag } & \multirow{2}{*}{ Rerata } \\
\cline { 2 - 4 } Media & $15 \times 20$ & $20 \times 20$ & $20 \times 25$ & \\
\hline $1: 2: 3$ & $33,6 \mathrm{~b}$ & $38,1 \mathrm{ab}$ & $40,1 \mathrm{ab}$ & $37,3 \mathrm{a}$ \\
$2: 1: 3$ & $33,3 \mathrm{ab}$ & $33,1 \mathrm{ab}$ & $39,4 \mathrm{a}$ & $35,3 \mathrm{a}$ \\
$3: 2: 1$ & $36,1 \mathrm{~b}$ & $36,0 \mathrm{ab}$ & $39,2 \mathrm{ab}$ & $37,1 \mathrm{a}$ \\
\hline Rerata & $34,3 \mathrm{~b}$ & $35,7 \mathrm{~b}$ & $39,6 \mathrm{a}$ & $(-)$ \\
\hline Keterangan: & Angka pada baris dan kolom yang diikuti dengan huruf yang sama tidak berbeda nyata \\
& menurut uji DMRT a5\%. (-) : Tidak terjadi interaksi antar faktor &
\end{tabular}

\section{g. Jumlah Buah Per Tanaman}

Hasil sidik ragam (Anova) menunjukkan tidak terjadi pengaruh interaksi antara komposisi media tanam dan ukuran polybag terhadap jumlah buah per tanaman.

Komposisi media tanam tidak berpengaruh nyata pada jumlah buah per tanaman tetapi data Tabel 7. menunjukkan bahwa tanaman yang ditanam pada media tanam dengan komposisi 1:2:3 cenderung lebih banyak sedangkan jumlah buah setiap tanaman yang ditanam pada media tanam dengan komposisi 3:2:1 paling sedikit. Ukuran polybag berpengaruh nyata terhadap jumlah buah per tanaman dimana buah setiap tanaman yang ditanam dalam polybag dengan ukuran $20 \times 25$ paling banyak dan berbeda nyata dengan jumlah buah setiap tanaman yang ditanam dalam polybag dengan ukuran $15 \times 20$ tetapi tidak berbeda nyata dengan jumlah buah setiap tanaman yang ditanam dalam polybag dengan ukuran $20 \times 20$.

\begin{tabular}{ccccc}
\multicolumn{3}{l}{ Tabel 7. Jumlah Buah Per Tanaman } \\
\cline { 1 - 3 } Komposisi & \multicolumn{3}{c}{ Ukuran Polybag } & \multirow{2}{*}{ Rerata } \\
\cline { 2 - 4 } Media & $15 \times 20$ & $20 \times 20$ & $20 \times 25$ & \\
\hline $1: 2: 3$ & $20,9 \mathrm{a}$ & $26,4 \mathrm{a}$ & $27,5 \mathrm{a}$ & $24,9 \mathrm{a}$ \\
$2: 1: 3$ & $17,7 \mathrm{a}$ & $28,1 \mathrm{a}$ & $28,1 \mathrm{a}$ & $24,6 \mathrm{a}$ \\
$3: 2: 1$ & $21,2 \mathrm{a}$ & $19,4 \mathrm{a}$ & $21,5 \mathrm{a}$ & $20,7 \mathrm{a}$ \\
\hline Rerata & $19,9 \mathrm{~b}$ & $24,6 \mathrm{ab}$ & $25,7 \mathrm{a}$ & $(-)$ \\
\hline Keterangan : & Angka pada baris dan kolom yang diikuti dengan huruf yang sama tidak berbeda nyata & menurut uji DMRT a5\%. (-) : Tidak terjadi interaksi antar faktor
\end{tabular}

h. Berat Buah Per Tanaman

Hasil sidik ragam (Anova) menunjukkan terjadi pengaruh interaksi antara komposisi media tanam dan ukuran polybag terhadap berat buah per tanaman saat panen III dimana buah setiap tanaman yang ditanam pada media tanam dengan komposisi 2:1:3 dalam polybag dengan ukuran $20 \times 25$ paling berat yang berbeda nyata dengan berat buah setiap tanaman yang ditanam pada media tanam dengan komposisi yang sama dalam polybag dengan ukuran $15 \times 20$, komposisi 2:1:3 dalam polybag dengan ukuran $15 \times 20$ dan $20 \times 20$, komposisi 3:2:1 dalam polybag dengan ukuran $20 \times 20$ dan $20 \times 25$ tetapi tidak berbedanya nyata dengan berat buah setiap tanaman yang diberikan kombinasi perlakuan lainnya.

Komposisi media tanam maupun ukuran polybag memberikan pengaruh utama yang nyata terhadap berat buah per tanaman panen I, panen II dan panen III tetapi saat panen IV pengaruh utama komposisi media tanam maupun ukuran polybag tidak terjadi lagi. Saat panen I buah per tanaman yang ditanam pada media tanam dengan komposisi $2: 1: 3$ paling berat dan berbeda nyata dengan buah setiap tanaman yang ditanam pada media tanam dengan komposisi
3:2:1 tetapi tidak berbeda nyata dengan berat buah setiap tanaman yang ditanam pada media tanam dengan komposisi 1:2:3. Berat buah per tanaman yang ditanam dalam polybag dengan ukuran $20 \times 25$ paling berat dan berbeda nyata dengan berat buah setiap tanaman yang ditanam dalam polybag dengan ukuran 15 x 20 tetapi tidak berbeda nyata dengan berat buah setiap tanaman yang ditanam dalam polybag dengan ukuran $20 \times 20$.

Saat panen II buah per tanaman yang ditanam pada media tanam dengan komposisi 1:2:3 paling berat dan berbeda nyata dengan buah setiap tanaman yang ditanam pada media tanam dengan komposisi 3:2:1 tetapi tidak berbeda nyata dengan berat buah setiap tanaman yang ditanam pada media tanam dengan komposisi 2:1:3. Berat buah per tanaman yang ditanam dalam polybag dengan ukuran $20 \times 25$ paling berat dan berbeda nyata dengan berat buah setiap tanaman yang ditanam dalam polybag dengan ukuran $15 \times 20$ tetapi tidak berbeda nyata dengan berat buah setiap tanaman yang ditanam dalam polybag dengan ukuran $20 \times 20$. Saat panen III buah per tanaman yang ditanam pada media tanam dengan komposisi 1:2:3 paling berat dan berbeda nyata dengan buah setiap tanaman yang ditanam pada media tanam dengan komposisi 2:1:3 
tetapi tidak berbeda nyata dengan berat buah setiap tanaman yang ditanam pada media tanam dengan komposisi 3:2:1. Berat buah per tanaman yang ditanam dalam polybag dengan ukuran $20 \times 25$ paling berat dan berbeda nyata dengan berat buah setiap tanaman yang ditanam dalam polybag dengan ukuran $15 \times 20$ maupun $20 \times 20$.

Tabel 8. Berat Buah Per Tanaman (g)

\begin{tabular}{|c|c|c|c|c|c|}
\hline \multirow{2}{*}{$\begin{array}{c}\text { Waktu } \\
\text { Pengamatan }\end{array}$} & \multirow{2}{*}{$\begin{array}{c}\text { Komposisi } \\
\text { Media }\end{array}$} & \multicolumn{3}{|c|}{ Ukuran Polybag } & \multirow{2}{*}{ Rerata } \\
\hline & & $15 \times 20$ & $20 \times 20$ & $20 \times 25$ & \\
\hline \multirow{4}{*}{ Panen I } & $1: 2: 3$ & $174,8 \mathrm{a}$ & $181,6 \mathrm{a}$ & $217,0 \mathrm{a}$ & $191,1 \mathrm{ab}$ \\
\hline & $2: 1: 3$ & $147,4 \mathrm{a}$ & $243,2 \mathrm{a}$ & $230,8 \mathrm{a}$ & $207,1 \mathrm{a}$ \\
\hline & $3: 2: 1$ & $124,1 \mathrm{~b}$ & $130,4 \mathrm{ab}$ & $187,1 \mathrm{a}$ & $147,2 \mathrm{~b}$ \\
\hline & Rerata & $148,8 \mathrm{~b}$ & $185,1 \mathrm{ab}$ & $211,6 \mathrm{a}$ & $(-)$ \\
\hline \multirow{4}{*}{ Panen II } & $1: 2: 3$ & $236,3 \mathrm{c}$ & $359,0 \mathrm{ab}$ & $412,8 \mathrm{a}$ & $336,0 \mathrm{a}$ \\
\hline & $2: 1: 3$ & $219,2 \mathrm{c}$ & $301,8 \mathrm{bc}$ & $360,7 \mathrm{ab}$ & $293,9 \mathrm{ab}$ \\
\hline & $3: 2: 1$ & $249,0 \mathrm{c}$ & $227,9 \mathrm{c}$ & $268,2 \mathrm{bc}$ & $248,4 \mathrm{~b}$ \\
\hline & Rerata & $234,9 \mathrm{~b}$ & $296,2 \mathrm{a}$ & $347,2 \mathrm{a}$ & $(-)$ \\
\hline \multirow{4}{*}{ Panen III } & $1: 2: 3$ & $158,9 \mathrm{~cd}$ & $209,7 \mathrm{abc}$ & $250,9 \mathrm{a}$ & $206,5 \mathrm{a}$ \\
\hline & $2: 1: 3$ & $127,6 \mathrm{~d}$ & $183,9 \mathrm{bc}$ & $219,6 \mathrm{ab}$ & $177,0 \mathrm{~b}$ \\
\hline & $3: 2: 1$ & $204,2 \mathrm{abc}$ & $179,1 \mathrm{bc}$ & $197,9 \mathrm{bc}$ & $193,7 \mathrm{ab}$ \\
\hline & Rerata & $163,5 \mathrm{c}$ & $190,9 \mathrm{~b}$ & $222,8 \mathrm{a}$ & $(+)$ \\
\hline \multirow{4}{*}{ Panen IV } & $1: 2: 3$ & $176,6 \mathrm{a}$ & $274,4 \mathrm{a}$ & $241,6 \mathrm{a}$ & $230,8 \mathrm{a}$ \\
\hline & $2: 1: 3$ & $160,3 \mathrm{a}$ & $236,4 \mathrm{a}$ & $290,2 \mathrm{a}$ & $228,9 \mathrm{a}$ \\
\hline & $3: 2: 1$ & $293,0 \mathrm{a}$ & $234,7 \mathrm{a}$ & $191,2 \mathrm{a}$ & $239,7 \mathrm{a}$ \\
\hline & Rerata & $210,0 \mathrm{a}$ & $248,5 \mathrm{a}$ & $241,0 \mathrm{a}$ & $(-)$ \\
\hline \multirow{4}{*}{ Total Panen } & $1: 2: 3$ & $746,6 \mathrm{bc}$ & $1024,6 \mathrm{ab}$ & $1122,3 \mathrm{a}$ & $964,5 \mathrm{a}$ \\
\hline & $2: 1: 3$ & $654,5 \mathrm{c}$ & $965,3 \mathrm{ab}$ & $1101,3 \mathrm{a}$ & $907,0 \mathrm{a}$ \\
\hline & $3: 2: 1$ & 870,3 abc & $772,2 \mathrm{bc}$ & $844,4 \mathrm{abc}$ & $829,0 \mathrm{a}$ \\
\hline & Rerata & $757,1 \mathrm{~b}$ & $920,7 \mathrm{a}$ & $1022,7 \mathrm{a}$ & $(-)$ \\
\hline
\end{tabular}

Saat panen IV buah per tanaman yang ditanam pada media tanam dengan komposisi 3:2:1 cenderung lebih berat sedangkan buah setiap tanaman yang ditanam pada media tanam dengan komposisi 2:1:3 paling ringan. Buah per tanaman yang ditanam dalam polybag dengan ukuran 20 x 20 cenderung lebih berat sedangkan buah setiap tanaman yang ditanam dalam polybag dengan ukuran 15 x 20 paling ringan.

Komposisi media tidak berpengaruh nyata terhadap berat buah total panen tetapi buah per tanaman yang ditanam pada media tanam dengan komposisi 1:2:3 cenderung lebih berat sedangkan buah setiap tanaman yang ditanam pada media tanam dengan komposisi 3:2:1 paling ringan. Ukuran polybag berpengaruh nyata terhadap berat buah per tanaman total panen panen dimana buah per tanaman yang ditanam dalam polybag dengan ukuran $20 \times 25$ paling berat dan berbeda nyata dengan berat buah setiap tanaman yang ditanam dalam polybag dengan ukuran 15 x 20 tetapi tidak berbeda nyata dengan berat buah setiap tanaman yang ditanam dalam polybag dengan ukuran $20 \times 20$.

i. Panjang Akar

Hasil sidik ragam (Anova) menunjukkan tidak terjadi pengaruh interaksi antara komposisi media tanam dan ukuran polybag terhadap panjang akar.

Komposisi media tanam tidak berpengaruh nyata terhadap panjang akar tetapi data pada Tabel 9. menunjukkan bahwa akar dari tanaman yang ditanam pada media tanam dengan komposisi 2:1:3 cenderung lebih panjang sedangkan akar dari tanaman yang ditanam pada media tanam dengan komposisi 3:2:1 paling pendek. Ukuran polybag juga tidak berpengaruh nyata terhadap panjang akar tetapi akar dari tanaman yang ditanam dalam polybag dengan ukuran $20 \mathrm{x}$ 25 cenderung lebih panjang sedangkan akar dari tanaman yang ditanam dalam polybag dengan ukuran $15 \times 20$ paling pendek.

Tabel 9. Panjang akar $(\mathrm{cm})$

\begin{tabular}{ccccc}
\hline Komposisi & \multicolumn{3}{c}{ Ukuran Polybag } & \multirow{2}{*}{ Rerata } \\
\cline { 2 - 4 } Media & $15 \times 20$ & $20 \times 20$ & $20 \times 25$ & \\
\hline $1: 2: 3$ & $26,9 \mathrm{~b}$ & $32,1 \mathrm{ab}$ & $34,3 \mathrm{a}$ & $31,1 \mathrm{a}$ \\
$2: 1: 3$ & $30,1 \mathrm{ab}$ & $31,9 \mathrm{ab}$ & $34,8 \mathrm{a}$ & $32,3 \mathrm{a}$ \\
$3: 2: 1$ & $31,3 \mathrm{ab}$ & $28,3 \mathrm{ab}$ & $30,0 \mathrm{ab}$ & $29,8 \mathrm{a}$ \\
\hline Rerata & $29,4 \mathrm{a}$ & $30,8 \mathrm{a}$ & $33,0 \mathrm{a}$ & $(-)$ \\
\hline Keterangan: & Angka pada baris dan kolom yang dikuti dengan huruf yang sama tidak berbeda nyata \\
& menurut uji DMRT a5\%. (-): Tidak terjadi interaksi antar faktor &
\end{tabular}

j. Berat Segar Berangkasan

Hasil sidik ragam (Anova) menunjukkan tidak terjadi pengaruh interaksi antara komposisi media tanam dan ukuran polybag terhadap berat segar berangkasan.

Komposisi media tanam berpengaruh nyata pada berat segar berangkasan dimana berangkasan segar dari tanaman yang ditanam pada media tanam dengan komposisi 2:1:3 paling berat dan berbeda nyata dengan berangkasan segar dari tanaman yang ditanam pada media tanam dengan komposisi 3:2:1 tetapi tidak berbeda nyata dengan berangkasan segar dari tanaman yang ditanam pada media tanam dengan komposisi 1:2:3.

Ukuran polybag juga berpengaruh nyata terhadap berat segar berangkasan dimana berangkasan segar dari tanaman yang ditanam dalam polybag dengan ukuran 20 x 25 paling berat dan berbeda nyata dengan berat segar berangkasan dari tanaman yang ditanam dalam polybag dengan ukuran 15 x 20 maupun $20 \times$ 20.

$\underline{\text { Tabel 10. Berat Segar Berangkasan (g) }}$

\begin{tabular}{ccccc}
\hline Komposisi & \multicolumn{3}{c}{ Ukuran Polybag } & \multirow{2}{*}{ Rerata } \\
\cline { 2 - 4 } Media & $15 \times 20$ & $20 \times 20$ & $20 \times 25$ & \\
\hline $1: 2: 3$ & $331,4 \mathrm{c}$ & $345,0 \mathrm{c}$ & $454,8 \mathrm{a}$ & $377,1 \mathrm{a}$ \\
$2: 1: 3$ & $348,1 \mathrm{c}$ & $433,8 \mathrm{ab}$ & $446,2 \mathrm{a}$ & $409,4 \mathrm{a}$ \\
$3: 2: 1$ & $322,1 \mathrm{c}$ & $331,1 \mathrm{c}$ & $352,4 \mathrm{c}$ & $335,2 \mathrm{~b}$ \\
\hline Rerata & $333,9 \mathrm{c}$ & $370,0 \mathrm{~b}$ & $417,8 \mathrm{a}$ & $(-)$ \\
\hline Keterangan : & Angka pada baris dan kolom yang diikuti dengan huruf yang sama tidak berbeda nyata \\
& menurut uji DMRT a5\%. (-): Tidak terjadi interaksi antar faktor &
\end{tabular}

\section{k. Berat Kering Akar}

Hasil sidik ragam (Anova) menunjukkan tidak terjadi pengaruh interaksi antara komposisi media tanam dan ukuran polybag terhadap berat kering akar.

Komposisi media tanam tidak berpengaruh nyata terhadap berat kering akar tetapi data pada Tabel 11. menunjukkan bahwa akar dari tanaman yang ditanam pada media tanam dengan komposisi 2:1:3 cenderung lebih berat sedangkan akar dari tanaman yang ditanam pada media tanam dengan komposisi 3:2:1 paling ringan.

Ukuran polybag berpengaruh nyata terhadap berat kering akar dimana akar dari tanaman yang ditanam dalam polybag dengan ukuran $20 \times 25$ paling berat dan berbeda nyata dengan berat kering akar dari tanaman yang ditanam dalam polybag dengan ukuran 15 × 20 tetapi tidak berbeda nyata dengan berat kering akar dari tanaman yang ditanam dalam polybag dengan ukuran 20 x 20 . 
Tabel 11. Berat Kering Akar (g)

\begin{tabular}{ccccc}
\hline Komposisi & \multicolumn{3}{c}{ Ukuran Polybag } & \multirow{2}{*}{ Rerata } \\
\cline { 2 - 4 } Media & $15 \times 20$ & $20 \times 20$ & $20 \times 25$ & \\
\hline $1: 2: 3$ & $2,6 \mathrm{c}$ & $3,3 \mathrm{abc}$ & $3,5 \mathrm{ab}$ & $3,1 \mathrm{a}$ \\
$2: 1: 3$ & $2,9 \mathrm{abc}$ & $3,1 \mathrm{abc}$ & $3,6 \mathrm{a}$ & $3,2 \mathrm{a}$ \\
$3: 2: 1$ & $2,7 \mathrm{bc}$ & $2,7 \mathrm{bc}$ & $3,0 \mathrm{abc}$ & $2,8 \mathrm{a}$ \\
\hline Rerata & $2,7 \mathrm{~b}$ & $3,0 \mathrm{ab}$ & $3,4 \mathrm{a}$ & $(-)$ \\
\hline Keterangan : & Angka pada baris dan kolom yang diikuti dengan huruf yang sama tidak berbeda nyata \\
& menurut uji DMRT a5\%. (-) : Tidak terjadi interaksi antar faktor
\end{tabular}

1. Berat Kering Berangkasan

Hasil sidik ragam (Anova) menunjukkan tidak terjadi pengaruh interaksi antara komposisi media tanam dan ukuran polybag terhadap berat kering berangkasan.

Komposisi media tanam berpengaruh nyata pada berat kering berangkasan dimana berangkasan kering dari tanaman yang ditanam pada media tanam dengan komposisi 2:1:3 paling berat dan berbeda nyata dengan berangkasan kering dari tanaman yang ditanam pada media tanam dengan komposisi 3:2:1 tetapi tidak berbeda nyata dengan berangkasan kering dari tanaman yang ditanam pada media tanam dengan komposisi 1:2:3.

Ukuran polybag juga berpengaruh nyata terhadap berat kering berangkasan dimana berangkasan kering dari tanaman yang ditanam dalam polybag dengan ukuran 20 x 25 paling berat dan berbeda nyata dengan berat kering berangkasan dari tanaman yang ditanam dalam polybag dengan ukuran $15 \times 20$ maupun $20 \times$ 20.

Tabel 12. Berat Kering Berangkasan (g)

\begin{tabular}{ccccc}
\hline Komposisi & \multicolumn{3}{c}{ Ukuran Polybag } & \multirow{2}{*}{ Rerata } \\
\cline { 2 - 4 } Media & $15 \times 20$ & $20 \times 20$ & $20 \times 25$ & \\
\hline $1: 2: 3$ & $37,4 \mathrm{bcd}$ & $52,7 \mathrm{~b}$ & $55,3 \mathrm{~b}$ & $48,5 \mathrm{a}$ \\
$2: 1: 3$ & $34,7 \mathrm{~cd}$ & $55,4 \mathrm{~b}$ & $74,2 \mathrm{a}$ & $54,8 \mathrm{a}$ \\
$3: 2: 1$ & $31,9 \mathrm{~d}$ & $35,7 \mathrm{~cd}$ & $44,3 \mathrm{bcd}$ & $37,3 \mathrm{~b}$ \\
\hline Rerata & $34,7 \mathrm{c}$ & $47,9 \mathrm{~b}$ & $57,9 \mathrm{a}$ & $(-)$ \\
\hline Keterangan $:$ & Angka pada baris dan kolom yang diikuti dengan huruf yang sama tidak berbeda nyata \\
& menurut uji DMRT a5\%. (-) : Tidak terjadi interaksi antar faktor &
\end{tabular}

m. Rasio Akar Tajuk

Hasil sidik ragam (Anova) menunjukkan tidak terjadi pengaruh interaksi antara komposisi media tanam dan ukuran polybag terhadap rasio akar tajuk.

Komposisi media tanam tidak berpengaruh nyata terhadap rasio akar tajuk tetapi data pada Tabel 13. menunjukkan bahwa rasio akar tajuk dari tanaman yang ditanam pada media tanam dengan komposisi $3: 2: 1$ cenderung lebih tinggi sedangkan rasio akar tajuk dari tanaman yang ditanam pada media tanam dengan komposisi 1:2:3 dan 2:1:3 lebih rendah. Ukuran polybag juga tidak berpengaruh nyata terhadap rasio akar tajuk tetapi rasio akar tajuk dari tanaman yang ditanam dalam polybag dengan ukuran $15 \times 20$ cenderung lebih tinggi sedangkan rasio akar tajuk dari tanaman yang ditanam dalam polybag dengan ukuran $20 \times 25$ paling rendah.

$\underline{\text { Tabel 13. Rasio Akar Tajuk }}$

\begin{tabular}{ccccc}
\hline Komposisi & \multicolumn{3}{c}{ Ukuran Polybag } & \multirow{2}{*}{ Rerata } \\
\cline { 2 - 4 } Media & $15 \times 20$ & $20 \times 20$ & $20 \times 25$ & \\
\hline $1: 2: 3$ & $0,070 \mathrm{ab}$ & $0,063 \mathrm{ab}$ & $0,074 \mathrm{ab}$ & $0,069 \mathrm{a}$ \\
$2: 1: 3$ & $0,085 \mathrm{a}$ & $0,063 \mathrm{ab}$ & $0,050 \mathrm{~b}$ & $0,066 \mathrm{a}$ \\
$3: 2: 1$ & $0,084 \mathrm{a}$ & $0,077 \mathrm{ab}$ & $0,068 \mathrm{ab}$ & $0,076 \mathrm{a}$ \\
\hline Rerata & $0,080 \mathrm{a}$ & $0,068 \mathrm{a}$ & $0,064 \mathrm{a}$ & $(-)$ \\
\hline Keterangan : & Angka pada baris dan kolom yang diikuti dengan huruf yang sama tidak berbeda nyata \\
& menurut uji DMRT a5\%. (-) : Tidak terjadi interaksi antar faktor &
\end{tabular}

n. Indeks Panen

Hasil sidik ragam (Anova) menunjukkan tidak terjadi pengaruh interaksi antara komposisi media tanam dan ukuran polybag terhadap indeks panen.

Komposisi media tanam tidak berpengaruh nyata terhadap indeks panen tetapi data pada Tabel 14. menunjukkan bahwa indeks panen dari tanaman yang ditanam pada media tanam dengan komposisi 1:2:3 cenderung lebih tinggi sedangkan indeks panen dari tanaman yang ditanam pada media tanam dengan komposisi 3:2:1 paling rendah. Ukuran polybag juga tidak berpengaruh nyata terhadap indeks panen tetapi indeks panen dari tanaman yang ditanam dalam polybag dengan ukuran 20 x 20 cenderung lebih tinggi sedangkan indeks panen dari tanaman yang ditanam dalam polybag dengan ukuran 15 × 20 paling rendah.

Tabel 14. Indeks Panen (\%)

\begin{tabular}{ccccc}
\hline Komposisi & \multicolumn{3}{c}{ Ukuran Polybag } & \multirow{2}{*}{ Rerata } \\
\cline { 2 - 4 } Media & $15 \times 20$ & $20 \times 20$ & $20 \times 25$ & \\
\hline $1: 2: 3$ & $69,2 \mathrm{ab}$ & $74,7 \mathrm{a}$ & $71,1 \mathrm{ab}$ & $71,7 \mathrm{a}$ \\
$2: 1: 3$ & $64,5 \mathrm{~b}$ & $68,5 \mathrm{ab}$ & $71,0 \mathrm{ab}$ & $68,0 \mathrm{a}$ \\
$3: 2: 1$ & $72,8 \mathrm{a}$ & $69,9 \mathrm{ab}$ & $70,4 \mathrm{ab}$ & $71,0 \mathrm{a}$ \\
\hline Rerata & $68,8 \mathrm{a}$ & $71,0 \mathrm{a}$ & $70,8 \mathrm{a}$ & $(-)$ \\
\hline Keterangan: & Angka pada baris dan kolom yang diikuti dengan huruf yang sama tidak berbeda nyata \\
& menurut uji DMRT a5\%. (- ) : Tidak terjadi interaksi antar faktor &
\end{tabular}

\section{o. Pembahasan}

Tanaman yang ditanam pada media tanam berupa campuran tanah, arang sekam dan pupuk kandang dengan komposisi 1:2:3 berukuran paling pendek tetapi batangnya paling besar dengan permukaan daun yang tidak terlalu luas. Jumlah buah setiap tanaman yang dihasilkan paling banyak dengan ukuran buah yang paling besar dan paling berat sehingga saat panen II, panen III hingga total panen yang dihasilkan paling berat.

Penggunaan polybag berukuran 20 × 25 memberikan kondisi lingkungan berupa suhu tanah yang lebih rendah pada setiap kali pengamatan. Ukuran tanaman yang ditanam dalam polybag ukuran $20 \times 25$ paling pendek dengan batang yang sedang tetapi memiliki permukaan yang paling luas. Tanaman yang ditanam pada polybag yang berukuran $20 \times 25$ menghasilkan buah yang paling besar sehingga setiap buahnya juga lebih berat, dengan jumlah buah pada setiap tanaman yang juga lebih banyak maka buah setiap tanam juga paling berat. Jumlah buah setiap petak juga paling banyak sehingga pada setiap kali panen tanaman yang ditanam pada polybag yang berukuran $20 \times 25$ menghasilkan buah setiap petak yang paling berat.

Secara umum peningkatan ukuran polybag dalam hal ini semakin banyak volume media yang digunakan, diikuti oleh peningkatan hasil total panen tomat. Volume setiap jenis media tanam yang digunakan dalam setiap ukuran polybag dapat dilihat pada Tabel 15. berikut : 
Savana Cendana 1 (1) 1-7

Jurnal Pertanian Konservasi Lahan Kering

International Standard of Serial Number 2477-7927

Tabel 15. Volume Setiap Jenis Media dalam Polybag $\left(\mathrm{cm}^{3}\right)$

\begin{tabular}{ccrrr}
\hline Ukuran & \multirow{3}{*}{ Jenis Media } & \multicolumn{3}{c}{ Komposisi Media } \\
\cline { 3 - 5 } Polybag & & $1: 2: 3$ & $2: 1: 3$ & $3: 2: 1$ \\
\hline \multirow{3}{*}{$15 \times 20$} & Tanah & 785 & 1570 & 2355 \\
& Arang Sekam & 1570 & 785 & 1570 \\
& Pupuk Kandang & 2355 & 2355 & 785 \\
\cline { 2 - 5 } & Total & 4710 & 4710 & 4710 \\
\hline \multirow{3}{*}{$20 \times 20$} & Tanah & 1047 & 2093 & 3140 \\
& Arang Sekam & 2093 & 1047 & 2093 \\
& Pupuk Kandang & 3140 & 3140 & 1047 \\
\cline { 2 - 5 } $20 \times 25$ & Total & 6280 & 6280 & 6280 \\
& Tanah & 1635 & 3271 & 4906 \\
& Arang Sekam & 3271 & 1635 & 3271 \\
\cline { 2 - 5 } & Pupuk Kandang & 4906 & 4906 & 1635 \\
\cline { 2 - 5 } & Total & 9813 & 9813 & 9813 \\
\hline
\end{tabular}

\section{Simpulan}

Dari hasil analisis dan pembahasan yang dilakukan maka dapa disimpulkan beberapa hal sebagai berikut:

a. Interaksi antara komposisi media tanam dan ukuran polybag hanya terjadi pada tinggi tanaman 14 HST dan berat buah per tanaman panen III.

b. Komposisi media tanam berpengaruh nyata terhadap diameter batang 28 HST dan 42 HST, berat buah per tanaman panen I, panen II dan panen III, berat segar maupun kering berangkasan. Sedangkan ukuran polybag berpengaruh nyata terhadap suhu tanah setiap waktu pengamatan, tinggi tanaman 14 HST dan 28 HST, diameter batang 28 HST, luas daun, berat per buah, jumlah buah per tanaman, berat buah per tanaman panen I, panen II, panen III dan total panen, berat segar maupun kering berangkasan dan berat kering akar.

c. Media tanam dengan komposisi 1:2:3 memberikan hasil total panen per tanaman tertinggi yakni 964,5 g dibandingkan komposisi media tanam $2: 1: 3$ dan $3: 2: 1$. Penggunaan polybag dengan ukuran $20 \times 25$ memberikan hasil total panen per tanaman tertinggi yaitu 1.022,7 $\mathrm{g}$ dibandingkan ukuran polybag $15 \times 20$ dan $20 \times 20$.

\section{Pustaka}

Ambarwati. 2008. Kajian Dosis Pupuk Urea dan Macam Media Tanam Terhadap Hasil Kandungan Andrographolide Tanaman Sambiloto (Andrographis Paniculata Ness). Fakultas Pertanian Sebelas Maret. Surakarta.

Anonim. 2007. Effective Microorganisms (EM) dan Bokashi Sebagai Agen Pengendali Hayati. [Internet]. [diunduh 2012 Mei 01].

Anonim. 2013. Pengaruh Penggosokan Benih dan Media Tanam Pada Perkecambahan Benih Karet (Havea brassiliensis). [Internet]. [diunduh 2015 Januari 13].
BPS TTU. 2007. Timor Tengah Utara Dalam Angka. BPS TTU. Kefamenanu. Gomez K A dan Gomez A A. 1995. Prosedur Statistik untuk Penelitian Pertanian. Edisi ke 2. Jakarta: UI Press.

Hayati E, Sabaruddin dan Rahmawati. 2012. Pengaruh Jumlah Mata Tunas Dan Komposisi Media Tanam Terhadap Pertumbuhan Setek Tanaman Jarak Pagar (Jatropha curcas L.) Jurnal Agrista Vol. 16 No. 3, 2012

Muliawati, E. S. 2001. Kajian Tingkat Serapan Hara, Pertumbuhan dan Produksi Sambiloto (Androgaphis Paniculata Ness.) pada Beberapa Komposisi Media Tanam dan Tingkat Pengairan. Prosiding Simposium Nasional II Tumbuhan Obat dan Aromatik. APINMAP. Bogor, 8-10 Agustus 2001.

Nyakpa, M.Y. \& Hasinah HAR. 1985. Pupuk dan Pemupukan. Fakultas Pertanian Unsyiah, Darussalam Banda Aceh.

Osman, F. 1996. Memupuk Tanaman Padi dan Palawija. Penebar Swadaya, Jakarta.

Prastowo N. dan J. M. Roshetko. 2006. Tehnik pembibitan dan perbanyakan vegetatif tanaman buah. World Agroforestry Centre. [Internet]. [diunduh 2015 Mater 03].

Prihmantoro dan Indriani, 2003. Pengaruh macam media dan intensitas pemupukan terhadap pertumbuhan bibit tanaman anthurium gelombang cinta (Anthurium plowmanii).Fakultas Pertanian Sebelas Maret. Surakarta.

Rifai, B \& S. R. Soebroto. 1982. Ilmu Memupuk II. CV. Yasa Guna, Jakarta.

Susanto dan Saneto. 1994. Komposisi Zat Gisi Buah Tomat. Jakarta

Wira. N.J. 2000. Pengaruh Campuran Bahan Organik Terhadap Pertumbuhan dan Hasil Tanaman Seledri. (Skripsi). Fakultas Pertanian. Universitas Mataram.149h.

Wuryaningsih. S. 2008. Media Tanam Tanaman Hias. [Internet]. [diunduh 2011 Juni 16]. 